\title{
JUMAT BERSIH
}

\section{NAMA : NUR AZIZAH AINUN RAZAK \\ NIM: 9173770410043}

Email: andiainun606@gmail.com

\section{Bentuk Kegiatan}

Jumat bersih

\section{Lokasi}

Mesjid Nurul Khairot, Dusun Kampung Beru

3.Hari/Tanggal

dan

Waktu

Rabu, 09 Oktober 2020

Jam 07:30

\section{Peserta yang Dilibatkan}

Mahasiswa KKLP STIESTKIP

JENEPONTO

\section{Alasan Diadakannya}

Agar mesjid itu bersih dan nyaman ketika masyarakat melaksanakan sholat jumat.

\section{Tujuan dan Manfaat}

Tujuannya: dari kegiatan ini menanamkan kesadaran kepada masyarakat bahwa betapa pentingnya kebersihan lingkungan baik dimesjid maupun sekitarnya. Mamfaatnya:

bagi masyarakat dan masyarakat sebagai kegiatan rutin desa pada hari jumat sebelum melakukan ibadah sholat jumat.

7.Produk Kegiatan (Jika Ada)

Sapu lidi,sapu ijuk,pel, dan skop sampah.

\section{Deskripsi Kegiatan}

Kegiatan jumat bersih merupakan kegiatan rutinitas kelompok yang dilakukan setiap jumat 
dimesjid yang ada didesa balangloe tarowang. Timbulnya ide kegiatan adalah agar ada kesadaran masyarakat untuk membersihkan mesjid seminggu sekali ketika akan melaksanakan sholat jumat. Kegiatan jumat bersih merupakan rangsangan yang diberikan oleh mahasiswa KKLP STIE-STIKP YAPTI JENEPONTO kepada masyarakat untuk senantiasa menjaga kebersihan lingkungan menuju keluarga yang lebih sehat. 


\section{Referensi Wajib}

- HERIANTO, H., \& Amir, A. S. (2020, September 10). Pedoman Pelaksanaan Kuliah Kerja Lapangan Plus (KKLP) Mahasiswa STIE dan STKIP YAPTI Jeneponto. https://doi.org/10.31219/osf.io/7dvpk

\section{Referensi Tambahan (Jika Ada)}

